\title{
CONVITE OU ENCERRAMENTO DE CONVERSA: UMA QUESTÃO INTERCULTURAL
}

Fátima Marinho Fabrício Monteiro é professora da SEEDUC-RJ e de Português para estrangeiros como segunda língua. Está concluindo o mestrado em Estudos da Linguagem na PUC-Rio.

fatimafabricio2007@gmail.com

\section{Resumo}

O objetivo deste relato de experiência é chamar a atenção para o fato de que o ensino de uma língua estrangeira não se restringe a questões linguísticas, mas também inclui uma consciência cultural e intercultural, para que a interação na língua alvo se realize com sucesso.

\begin{abstract}
The intention of this experience report is to draw attention to the fact that the teaching of a foreign language is not restricted to language issues, but it also includes cultural and intercultural awareness, so that the interaction in the target language can be carried out successfully.
\end{abstract}

Como mantenho um relacionamento amistoso com meus alunos e, às vezes, faço o papel de conselheira, outro dia, um francês procurou-me para desabafar. Ele disse que, há oito meses, quando veio de Paris para o Rio de Janeiro, achou que iria se livrar ${ }^{1}$ de uma namorada, pois não tinha dado para ela o atual endereço nem o número do telefone. Logo que aqui chegou, trocou de e-mail e abriu uma nova conta no Facebook, usando um pseudônimo e cancelando a anterior. Então, questionei:

- Mas não teria sido melhor você ter desmanchado o namoro antes de vir para o Brasil? Por que não fez isso, já que não estava mais interessado nela?

- Porque ela é muito apaixonada por mim, e, sempre que eu falava em dar um tempo, ela não aceitava. Como eu já estava para vir para o Rio, continuei com ela até o dia da viagem. Achei que, tão distante e sem dar notícias, ela fosse perceber que não éramos mais namorados. Mas ela acabou me descobrindo no Face. Há dias, mandou-me uma mensagem, dizendo que chega amanhã e vai ficar na minha casa.

- Se você tivesse desmanchado o namoro antes de viajar, agora, não estaria passando por isso. O que pretende fazer?

- Não sei o que fazer! Tenho uma namorada brasileira que amo muito, mas sei que a Cecilie - o nome da francesa é Cecilie - não tem dinheiro suficiente para se hospedar em hotel. Estou preocupado com ela, também, porque a única língua que fala é francês, e eu, além da namorada brasileira, trabalho o dia todo. E, pior, como dizer a ela que não quero mais ficar com ela? Que tenho uma namorada?

- É, meu amigo, agora você não tem saída. A solução é dizer a verdade. Se tivesse sido sincero antes de vir para o Brasil, ela não teria vindo atrás de você.

Para encerrar a conversa, como, em outra ocasião, ele tinha se oferecido para jantar em minha casa, acrescentei:

- Quando ela chegar, leve-a para jantar lá em casa.

Aproveitando o feriado do dia seguinte, eu e meu marido passamos o dia todo numa praia distante com as crianças. Na volta, estávamos tão cansados que resolvemos comer na rua, para chegarmos a casa, tomarmos um banho e irmos dormir. Quando consegui convencer os meus filhos a irem para a cama, antes de eu ter tido tempo de

\footnotetext{
${ }^{1}$ Esse termo foi usado por Jean Marc, 23 anos, por tê-lo aprendido na linguagem coloquial da rua.
} 
tomar um banho morno e relaxante, o interfone toca. Oh, meu Deus! Só falta o porteiro me avisar que vai fechar a água! E o meu banho?!!!

Irritada pelo cansaço, atendo o interfone:

- Alô!

- Dona Fátima, o seu Jean Marc está aqui com uma moça. Eles podem subir?

- O QUÊ?!!! QUEM?!!!

Enquanto o porteiro confirmava o nome de quem estava lá embaixo, mil coisas me passaram pela cabeça. Meu Deus! O que fazer? Será que aconteceu alguma coisa? Como uma pessoa vai à casa da outra sem telefonar antes. E o meu banho?!!!! Não acredito que isto esteja acontecendo. Voltando à realidade, ouço o porteiro dizer:

- Dona Fátima, eles estão subindo.

Só deu tempo de trocar de roupa e ouvir a campainha. Ao abrir a porta, educadamente, com toda a cordialidade que nos é peculiar, recebi-os com um sorriso:

- Olá, que surpresa! Tudo bem? Entrem, por favor!

- Boa noite, Fátima! Esta é a Cecilie.

- Oh, Cecilie, muito prazer! Seja bem-vinda ao Brasil!

- Merci. Enchantée!

- Fiquem à vontade! Vamos sentar.

Com todos acomodados, e as crianças animadíssimas com as visitas, mesmo desconfiando de que talvez eles tivessem ido para jantar, fiz a pergunta que não queria calar:

- Aconteceu alguma coisa?

- Não. Ela chegou hoje à tarde e viemos jantar em sua casa.

- Mas... vieram jantar sem avisar?

- Você ontem me convidou para jantar em sua casa.

Não tinha sido exatamente um convite, entretanto concordei:

- Tudo bem, só que eu não esperava que fosse hoje. Nem fiz janta, pois chegamos há pouco da rua.

- Só viemos porque você disse para eu vir quando ela chegasse.

Que situação desagradável! Como que eu, que sempre sou gentil com as pessoas, vou dizer que sinto muito, que ele entendeu mal, e marco um outro dia por estar muito cansada? Não tenho coragem! Caramba, que falha tenho cometido ao trabalhar apenas a consciência cultural. Preciso trabalhar também a consciência intercultural para evitar que haja critical incidents, ou seja, choques culturais. Bem, para salvar a face deles e a minha, mesmo estando louca por um banho e para descansar, vou sugerir jantarmos no Capelinha. Será que ele vai aceitar? O tempo está passando, tenho que dizer alguma coisa.

- Jean, eu sou responsável por este mal-entendido. Como professora de PL2E, deveria ter esclarecido que, aqui, no Brasil, mesmo com toda a intimidade que há nas relações interpessoais entre familiares ou amigos, nós não vamos à casa dos outros sem antes telefonar. Se vocês tivessem chegado mais cedo, nem iriam nos encontrar. Então, o que poderia acontecer? Você poderia ficar zangado comigo e achar-me mal-educada. Nas interações entre pessoas de culturas diferentes, devemos ter uma consciência 
intercultural para não passarmos por situações desconfortáveis e, às vezes, até desagradáveis. Ao dizer-lhe: "Quando ela chegar, leve-a para jantar lá em casa.", o marcador de tempo "quando" pode indicar o tempo presente ao dia da chegada ou um futuro próximo. Nesse enunciado, o "quando" não é pontual. Além disso, esse tipo de enunciado não é, necessariamente, um convite. Pode ser apenas uma forma indiretiva de encerrar a conversa, uma preparação para a despedida. Para que seja um convite, temos que combinar direitinho o dia e a hora. E há sempre um telefonema para a confirmação do encontro. Nem todos percebem, mas as interações interculturais vão além dos conhecimentos linguísticos.

- Ah bom, por isso que, mesmo eu tendo um bom conhecimento do português, sempre cometo umas gafes.

- Exatamente. A construção das identidades nacionais será o tema de nossa próxima aula.

- Isso é muito interessante, Fátima!

- Bem, vamos comemorar a chegada da Cecilie num restaurante aqui em frente. Lá, eles servem uns pratos deliciosos!

Mais à vontade, Jean faz uma piadinha:

- Agora é para aceitar o convite, professora? Dizem que, no Brasil, quem convida paga a conta. Hahaha...

No restaurante, sem que a Cecilie ouvisse, ele me perguntou baixinho:

- Fátima, comemorar o que, se eu não queria que a Cecilie estivesse aqui?

- Sem comentários, Jean. (rsrsrs)

O jantar foi tranquilo e agradável. Interagi bem com a Cecilie e a convidei para passar um dia comigo, mas ela deveria aguardar o meu telefonema. Após a sobremesa, pagamos a conta, e, finalmente, eu pude atravessar a rua, dar outro banho nos meninos, tomar o meu e dormir o sono dos justos.

$\mathrm{Na}$ aula seguinte, com entusiasmo, entrei em sala:

- Boa noite, turma! Hoje assistiremos a um vídeo, para que entendam melhor as interações interculturais. No final da aula, vocês, em grupos de quatro, produzirão esquetes de situações interativas em que haja um choque cultural. Para que entendam melhor, eu e Jean vamos fazer um relato do que aconteceu conosco na semana passada. Foi um incidente que mostra a importância do tema em pauta.

As dinâmicas foram tão boas que, de 1 a 5 , todos atribuíram 5 àquela aula. Porém, o melhor de tudo foi os alunos tomarem consciência de que, para se comunicar em uma segunda língua, não basta aprender a gramática, o vocabulário e a pronúncia dessa língua. $\mathrm{O}$ aprendiz deve também ter consciência da própria cultura e da cultura do falante da língua alvo, ou seja, é preciso que os interlocutores tenham uma consciência intercultural. 